\title{
IMPLEMENTASI TEORI PEMBELAJARAN BLENDED LEARNING DALAM MENYEIMBANGKAN KAPABILITAS BELAJAR PADA ERA DIGITAL (STUDI KASUS DI PRODI PAI UNIVERSITAS ALMA ATA YOGYAKARTA)
}

\author{
Abdul Rohman, Mastur Anwar Hartanto \\ Pascasarjana UIN Sunan Kalijaga Yogyakarta \\ abdulrohman026@gmail.com, Anwar.hartanto2@gmail.com
}

\section{ABSTRAK}

The pattern of blended learning is a combination of conventional learning patterns and e-learning. The concept of blended learning applied at the University of Alma-ata uses the WEB system with a composition of blended learning patterns, $75 \%$ for conventional learning and $25 \%$ for e-learning. The implementation of the blended learning theory in balancing learning capabilities includes two classifications. Learning capabilities include five aspects, namely verbal information, cognitive strategies, intellectual skills, attitudes and motor skills. The five capabilities are divided into two classifications of blended learning theory, namely verbal information and cognitive strategies included in the classification of e-learning, this is because it places more emphasis on the knowledge aspect. Then the three other aspects fall into the classification of conventional learning, this is because the conventional learning process is carried out directly and face-to-face between educators and students, educators become a central figure in learning and play a role not only in conveying science but as explained by Alghazali, educators are al-mudaris, al-mualim, al-muaddib and al-walid.

Kata Kunci: Blended Learning, Kapabilitas belajar, Era Digital 


\section{A. PENDAHULUAN}

Perkembangan teknologi digital pada Era revolusi industry 4.0 saat ini telah membawa perubahan dan pengaruh yang sangat signifikan di berbagai aspek kehidupan manusia, termasuk di bidang pendidikan. Proses belajar berlangsung terus menerus dari waktu ke waktu sampai pada era digital saat ini. Era digital pada abad ini membawa dampak yang tidak dapat dipandang sebelah mata oleh dunia pendidikan khususnya di Indonesia. Implikasi globalisasi sangat berimbas pada bentuk pelayanan pendidikan yang diberikan oleh pendidik kepada peserta didik. ${ }^{1}$ Hoyles \& Legrange menegaskan bahwa teknologi digital adalah hal yang paling mempengaruhi system pendidikan di dunia saat ini. Hal ini disebabkan karena aspek efektivitas, efesiensi dan daya tarik yang ditawarkan oleh pembelajaran berbasis teknologi digital. ${ }^{2}$

Perkembangan pembelajaran yang pada awalnya menggunakan konsep tradisional atau tatap muka kemudian dikembangkan oleh para ahli dengan memanfaat teknologi informasi dan komunikasi. Pemanfaatan teknologi dalam dunia pendidikan khususnya dunia pembelajaran telah mengubah sistem pembelajaran pola konvensional atau pola tradisional menjadi pola modern yang bermedia teknologi informasi dan komunikasi atau Information and communication technology (ICT). Salah satu diantaranya adalah media computer dengan jaringan internet-nya yang pada akhirnya memunculkan pola pembelajaran e-learning. ${ }^{3}$

Pada pola pembelajaran e-learning atau bisa disebut juga dengan pola pembelajaran ICT ini, pembelajar dapat memilih materi pembelajaran berdasarkan minatnya sendiri, sehingga belajar menjadi menyenangkan, tidak membosankan, penuh motivasi, semangat, menarik perhatian, bisa belajar kapan saja dan dimana saja tidak terbatas oleh ruang dan waktu. ${ }^{4}$ Dalam kenyataannya pola pembelajaran e-learning tidak sepenuhnya membuat peserta didik semangat, penuh motivasi dan yang lainya, melainkan pola pembelajaran e-learning bisa juga menimbulkan peserta didik bermalas-malasan dalam pelaksanaan pembelajarannya dikarenakan tidak adanya pengawasan.

${ }^{1}$ I Ketut Widiara, "Blended Learning Sebagai Alternatif Pembelajaran Di Era Digital," Purwadita 2, no. 2 (2018) halm 50.

Arif Rahman \&DKK., Pendidikan Islam Di Era Revolusi Indusdtri 4.0 (Yogyakarta: Komojaya Press, 2019) halm 16.

3 Walib Abdullah, "Model Blended Learning Dalam Meningkatkan," FIKROTUNA, no. 1 (2018) halm 857.

${ }^{4}$ Husamah, Pembelajaran Bauran (Teori Blended Learning) (Malang: Prestasi Pustaka, 2014) halm 1 . 
Jika dianalisis lebih jauh pola pembalajaran e-learning lebih menekankan pada aspek kognitif atau keilmuannya saja, sedangkan dalam pembelajaran khusunya kurikulum 2013 bukan hanya aspek kognitif saja yang harus di kuasai peserta didik melainkan aspek afektif (sikap) dan psikomotorik (keterampilan) harus di ikut sertakan juga.

Pola pembelajaran e-learning juga memberikan dampak yang sangat signifikan terhadap peran pendidik, khususnya para pendidik agama Islam, sejatinya peran pendidik bukan hanya menyampaikan keilmuan saja melainkan pendidik merupakan sentral figur siswa seperti yang di jelaskan Alghazali pendidik merupakan al-mudaris, al-mualim, al-muaddib dan al-walid. Yang artinya bahwa secara fungsional pendidik adalah seorang yang melakukan kegiatan dalam memberikan pengetahuan, keterampilan, pengalaman, membentuk sikap spiritual anak, dan pendidik juga harus menjadi seorang yang patut di gugu dan di tiru, baik berupa kata maupun perbuatanya. ${ }^{5}$

Melihat beberapa permasalahan di atas pola pembelajaran konvensional atau tradisional secara tatap muka (face-to-face) masih sangat di butuhkan dan relevan karena pada sejatinya belajar merupakan proses dua arah, peserta didik memerlukan feedback dari pengajar dan sebaliknya pengajar juga memerlukan feedback dari peserta didik. Melalui pola pembelajaran ini akan didapat hasil belajar yang lebih efektif dan tepat sasaran. akan tetapi dalam mengikuti perkembangan zaman yang semakin canggih dengan era digitalisasinya pola pembelajaran e-learning juga sangat bagus untuk di terapkan, sehingga memudahkan seorang pendidik dalam menyampaikan materi pembelajaran dan mengembangkan pola pembelajaran yang bukan lagi menjadikan pendidik sebagai senter utama atau teacher centered dalam pembelajaran, melainkan mengubahnya dengan student centered dalam pembelajaran.

Oleh sebab itu untuk menyeimbangkan output dari pembelajaran yang mencakup tiga aspek penting dalam pembelajaran, perlu adanya teori yang mampu menyeimbangkan ketiga aspek tersebut. Dalam penelitian ini akan menggunakan teori blended learning, teori blended learning merupakan teori pembelajaran yang mengabungkan antara pola pembelajaran e-learning atau berbasis digitalisasi yang lebih menitik beratkan output aspek pengetahuan atau kognitif dengan pola pembelajaran konvensional atau tradisional yang lebih menitik beratkan output aspek psikomotorik atau keterampilan dan aspek afekif atau sikap, baik sikap sosial maupun sikap spiritual, serta pola pembel-

5 Suparta, Pengantar Dan Aplikasi Pengembangan Kurikulum PAI. (Jakarta: Rajawali, 2016) halm 132. 
ajaran konvensional juga membantu guru lebih memaksimalkan kembali perannya sebagai seorang pendidik. Dengan begitu untuk mengetahui seberapa relevan teori blended learning dalam menyeimbangkan tiga aspek pembelajaran di era digital, perlu adanya lembaga yang sedang atau sudah menerapkan teori ini. Berdasarkan pengamatan dan observasi peneliti mendapatkan tempat yang tepat untuk di teliti yaitu di Universitas Alma Ata Yogyakarta.

Alasan mengapa peneliti memilih tempat penelitian di Universitas Alma Ata, berdasarkan hasil wawancara dengan salah satu mahasiswa PAI Universitas Alma Ata, Ia mengungkapkan bahwa seluruh perkuliahan setiap mata kuliah di Prodi PAI sudah menggunakan pola pembelajaran berbasis internet atau e-learning bahkan tersedia aplikasi pembelajarannya, akan tetapi dari empat belas pertemuan dalam pembelajaran, pola pembelajaran e-learning atau pembelajaran berbasis digital atau intenet hanya tiga kali pertemuan, kemudian 11 pertemuan lainya di gunakan untuk pembelajaran secara konvensional atau tatap muka dan penugasan di lapangan seperti mini riset dan yang lainya. ${ }^{6}$

Berdasarkan hasil wawancara menunjukan bahwa pola pembelajaran yang di gunakan di Prodi PAI Universitas Alma Ata menggunakan perpaduan antara pola pembelajaran konvensional dan pola pembelajaran berbasis internet atau e-learning. Dengan hal itu adanya keselarasan dengan teori yang di gunakan dalam penelitian yaitu teori blended learning. Dimana teori blended learning sendiri menggabungkan dan mengkombinasikan dua teori pembelajaran yaitu pembelajaran konvensional dan elearning.

Maka dari itu dalam penelitian berbasis lapangan ini peneliti ingin mengetahui seberapa relevankah pengaplikasian teori pembelajaran blended learning dalam menyeimbangkan kapabilitas belajar di era digital di Universitas Alma Ata Yogyakarta.

\section{B. KERANGKA TEORI}

Untuk menganalisis permasalahan yang berkaitan dengan pola pembelajaran di era digital, penulis menggunakan beberapa teori berikut sebagai acuan untuk menganalisis permasalahan tersebut:

\section{Teori Blended Learning}

Pada awalnya istilah Blended learning juga dikenal dengan konsep pembelajaran hiprida yang memadukan pembelajaran tatap muka, online dan offine

${ }^{6}$ Wawancara berbasis digital/Watshapp, Rizka : Mahasiswi prodi PAI angkatan 2018, (Jumat tanggal 11 oktober 2019) 
namun akhir ini berubah menjadi blended learning. Blended artinya campuran atau kombinasi sedangkan learning adalah pembelajaran. Pendapat pula dinyatakan oleh Graham bahwasannya blended learning merupakan perpaduan atau kombinasi dari berbagai pembelajaran yaitu mengkombinasikan pembelajaran tatap muka (face to face) dengan konsep pembelajaran tradisional yang sering dilakukan oleh praktisi pendidikan dengan melalui penyampaian materi langsung pada siswa dengan pembelajaran online dan offine yang menekankan pada pemanfaatan teknologi.?

Blended learning adalah sebuah konsep yang relatif baru dalam pembelajaran di mana intruksi yang di sampaikan melalui campuran pembelajaran online dan tradisional yang dalam pelaksanaanya di pimpin oleh pengajar atau instruktur. Tujuan pemebelajara blended learning adalah memberikan kesempatan bagi berbagai karakteristik pembelajar agar dapat belajar dengan mandiri, berkelanjutan, dan berkembang sepanjang hayat. ${ }^{8}$

Menurut Graham dalam kuntarto, pola Pembelajaran blended learning mempunyai dua tipe lingkungan pembelajaran, yakni ada lingkungan pembelajaran tatap muka secara tradisional (traditional face to face learning environment) yang masih digunakan di daerah perdesaan; dan distributed learning environment yang sudah mulai berkembang seiring dengan teknologi-teknologi baru yang memungkinkan perluasan untuk mendistribusikan komunikasi dan interaksi atau bisa yang biasa di sebut dengan pola pembelajaran $e$-learning. 9

Pembelajaran blended learning berkembang sekitar tahun 2000 dan sekarang banyak digunakan di Amerika Utara, Inggris dan Australia, dikalangan perguruan tinggi dan dunia pelatihan. Begitu juga di Indonesia sudah ada beberapa universitas yang menerapkan pola pembelajaran blended learning ini. Pembelajaran berbasis blended learning merupakan kombinasi berbagai bentuk alat pembelajaran misalnya kombinasi real time perangkat lunak, program pembelajaran berbasis web online dan aplikasi lainnya yang mendukung pada lingkungan belajar dan pengetahuan manajemen sistem. Pembelajaran blended learning perpaduan antara online, tatap muka dan mandiri yang

\footnotetext{
7 Charkes R Graham Antony G. Piccianon, Charles D, Dziuban, Blended Learning Research Perspestive (New York: Routledge, 2014) halm 4.

8 Wasis D. Dwiyogo, Pemebelajaran Berbasis Blended Learning. (Depok: Rajawali Press, 2018) halm 60 .

9 Kuntarto \&DKK, "Pengembangan Model Pembelajaran Blended Learning Pada Aspek Learning Design Dengan Platform Media Sosial Online Sebagai Pendudkung Perkuliahan Mahasiswa," 2016, http://repository.unja.ac.id/626/1/Artikel Jurnal-Blended Learning.pdf.
} 
dipandu oleh mentor, guru atau dosen dengan pembelajaran yang terstruktur berikut gambarannya. ${ }^{10}$

Pembelajaran berbasis blended learning, disamping untuk meningkatkan hasil belajar, bermanfaat pula untuk meningkatkan hubungan komunikasi pada tiga mode pembelajaran yaitu lingkungan pembelajaran yang berbasis ruang kelas tradisional, yang blended, dan yang sepenuhnya online. ${ }^{11}$

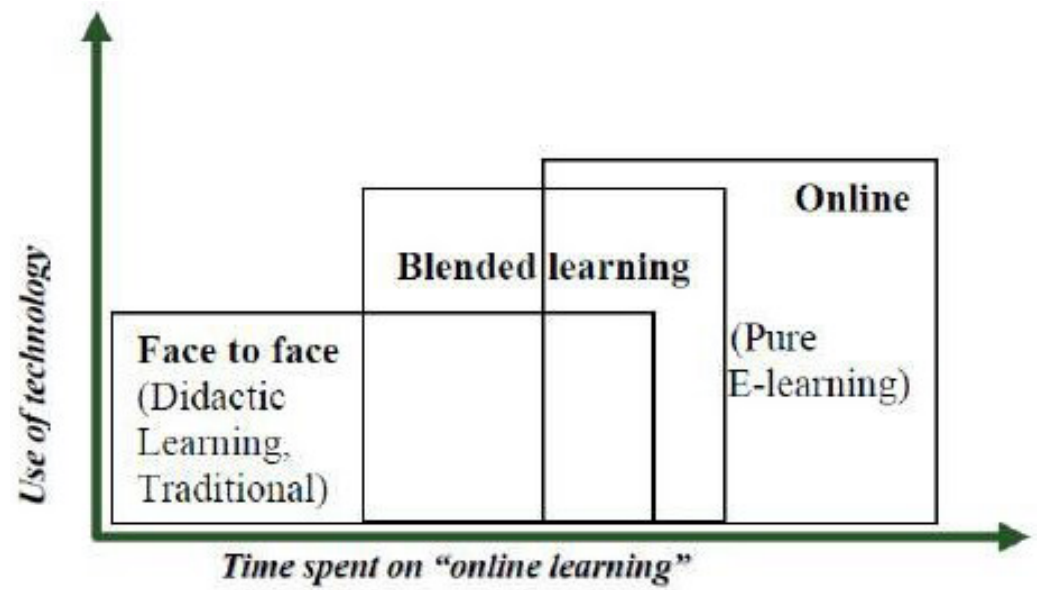

Konsep blended learning sumber: Henzi dan Procter (2004)

Menurut Driscoll dalam Ali mengidentifikasi empat konsep pembelajaran blended learning yaitu: ${ }^{12}$

a. Menggabungkan atau mencampur mode teknologi yang berbasis web misalnya kelas virtual langsung, pembelajaran kolaboratif, streaming video, audio dan teks.

b. Menggabungkan pendekatan pedagogis misalnya kognitivisme, konstruktivisme, behaviorisme, untuk menghasilkan pembelajaran yang optimal dengan atau tanpa penggunaan teknologi.

c. Menggabungkan segala bentuk teknologi pembelajaran misalnya video tape, $\mathrm{CD}$ - ROM, pelatihan berbasis web film dengan dipimpin

${ }^{10}$ Wasis D. Dwiyogo, Pemebelajaran Berbasis Blended Learning, halm 61.

${ }^{11}$ Husni Idris, "Pembelajaran Model Blended Learning," Jurnal Ilmiah Iqra' 5, no. 1 (2018): halm 62.

${ }^{12}$ Angela Carbone Ali alammary, Judy Sheard, "Blended Learning In Higher Education: Three Different Aproaches," Australian Journal of Educational Technology 1, no. 3 (2014) halm 34. 
instruktur tatap muka.

d. Mencampur atau mengadukkan teknologi pembelajaran yang sebenarnya untuk menciptakan efek pembelajaran dan kerja yang harmonis.

Komposisi blended learning yang sering digunakan yaitu dengan pola $50 / 50$, dalam alokasi waktu yang tersedia 50\% tatap muka 50\% pembelajaran online, juga ada pula yang menggunakan pola $75 / 25$, artinya $75 \%$ pertemuan tatap muka $25 \%$ pembelajaran online, dan ada juga yang menerapkan $25 / 75$, $25 \%$ menggunakan pembelajaran tatap muka $75 \%$ menggunakan pembelajaran online. ${ }^{13}$

Penggunaan pola tersebut tergantung dari analisis kompetensi yang dibutuhkan, mulai dari tujuan mata pelajaran, karakteristik peserta didik, karakteristik dan kemampuan peserta didik dan sumber daya yang tersedia. Namun pertimbangan utama dalam merancang komposisi pembelajaran yaitu penyediaan sumber belajar yang cocok untuk berbagai karakteristik peserta didik agar pembelajaran menjadi menarik efektif dan efisien.

Menurut Ruchi dan Sunita Dalam menggabungkan pola pembelajaran online dengan tatap muka yang disebut dengan blended learning beda dengan model pembelajaran lainnya. Blended learning juga mempunyai karakteristik tertentu diantaranya:

a. Proses pembelajaran yang menggabungkan berbagai model pembelajaran, gaya pembelajaran serta penggunaan berbagai media pembelajaran berbasis teknologi dan komunikasi.

b. Perpaduan antara pembelajaran mandiri via online dengan pembelajaran tatap muka guur dengan siswa serta menggabungkan pembelajaran mandiri.

c. Pembelajaran didukung dengan pembelajaran yang efektif dari cara penyampaian, cara belajar dan gaya pembelajarannya.

d. Dalam blended learning orang tua dengan guru juga mempunyai peran penting dalam pembelajaran anak didik guru merupakan fasilitator sedangkan orang tua sebagai motivator dalam pembelajaran anaknya.

e. Siswa dapat bersosialisasi dengan baik dengan sesama, siswa mempuanyai waktu banyak dan dapat melakukan feedback, siswa juga dipandu dengan baik serta siswa belajar dengan atmosfer yang ideal. ${ }^{14}$

${ }^{13}$ Wasis D. Dwiyogo, Pemebelajaran Berbasis Blended Learning, halm 62.

${ }^{14}$ Sunita Sungh Ruchi Shivam, "Implementation of Blended Learning In Classroom: 
Adapun unsur-unsur blended learning yaitu meliputi ranah pembelajaran online dan pembelajaran tatap muka. Unsur-unsur unsur tersebut meliputi: tatap muka dikelas, belajar mandiri, pemanfaatan aplikasi (web), tutorial, kerjasama, dan evaluasi. Dalam hal ini pendidik berperan sebagai fasilitator dan mediator dalam pengelolaan unsu-unsur tersebut. Pendidik menjelaskan dan memberi arahan pada peserta didiknya bagaimana menggunakan aplikasi yang digunakan dalam pembelajaran, pendidik juga memberi penjelasan materi sama seperti pembelajaran tatap muka namun pendidik hanya memanfaatkan media untuk tambahan materi atau untuk memberi tugas yang terstruktur pada peserta didik.

\section{Pembelajaran Tradisional/konvensioanal}

Pembelajaran Tradisional merupakan sebuah metode pembelajaran yang biasa digunakan oleh para tenaga pengajar sebagai proses komunikasi lisan antara pendidik dengan peserta didik dalam proses belajar dan pembelajaran. Model pembelajaran ini terpusat pada guru, mengutamakan hasil bukan proses, siswa ditempatkan sebagai objek dan bukan subjek pembelajaran sehingga siswa sulit untuk menyampaikan pendapatnya. Selain itu metode yang digunakan tidak terlepas dari ceramah, pembagian tugas dan latihan sebagai bentuk pengulangan dan pendalaman materi ajar. ${ }^{15}$

Pembelajaran konvensioanl/tradisional mempunyai beberapa keunggulan dan kelemahan yang harus diperhatikan oleh pendidik guna kelancaran dan keefektifan pembelajaran. Adapun keunggulan dari pola pembelajaran konvensional yaitu: ${ }^{16}$

a. Berbagai informasi yang tidak mudah ditemukan ditempat lain

b. Menyampaikan informasi dengan cepat

c. Membangkitkan minat akan informasi

d. Mengajari peserta didik cara belajar terbaiknya dengan mendengarkan, mengmati, bertanya, mengasosiasi dan mengaplikasikan

e. Memfungsikan peran sejati guru sebagai seorang mudaris, muadib

A Review Paper," Internasion al Journal of Scientific and Research Publication 20, no. 1 (2015).

${ }^{15}$ Ibrahim, "Perpaduan Model Pembelajaran Aktif Konvensional (Cermah) Dengan Cooperatif (Make-a Match) Untuk Meningkatkan Hasil Belajar Pendidikan Kewarganegaraan," Jurnal Ilmu Pendidikan Sosial, Sains Dan Humaniora 3, no. 2 (2017) halm 202.

${ }^{16}$ Daryanto \& Syaiful Karim, halm 119. 
dan mualim

f. Mengaplikasikan pembelajaran keteladanan dalam pribadi guru

g. Belajar menghormati pendapat orang lain atau toleransi

Sedangkan kelemahan pembelajaran konvensional adalah sebagai berikut:

a. Tidak semua peserta didik memiliki cara belajar terbaik dengan mendengarkan.

b. Sering terjadi kesulitan untuk menjaga agar peserta didik tetap tertarik dengan apa yang dipelajari.

c. Para peserta didik tidak mengatahui apa tujuan mereka belajar pada hari itu

d. Penekanan hanya pada penyelesaian tugas

e. Daya serapnya rendah dan cepat hilang karena bersifat mengahafal.

f. Pola pembelajaran membosankan dan satu arah

\section{Pembelajaran E-learning}

Pembelajaran E-learning merupakan metode penyampaian yang digunakan dalam pembelajaran jarak jauh. E-learning dapat di pahami sebagai metode penyampaian dengan menggunakan alat bantu seperti komputer, laptop, handpone yang memanfaatkan tekonologi internet serta pemrograman yang memungkinkan para peserta didik untuk berinteraksi dengan bahan bahan pelajaran melalui chat room (ruang komunikasi). ${ }^{17}$

Istilah e-learning banyak memiliki arti karena bermacam penggunaan $e$ learning saat ini. Pada dasarnya, e-learning memiliki dua tipe yaitu synchronous dan asynchronous. ${ }^{18}$ Synchronous berarti pada waktu yang sama. Proses pembelajaran terjadi pada saat yang sama antara pendidik dan peserta didik. Hal ini memungkinkan interaksi langsung antara pendidik dan peserta didik secara on line. Dalam pelaksanaan, synchronous training mengharuskan pendidik dan peserta didik mengakses internet secara bersamaan.

Sedangkan Asynchronous berarti tidak pada waktu bersamaan. Peserta didik dapat mengambil waktu pembelajaran berbeda dengan pendidik memberikan materi. Asynchronous training terkenal dalam e-learning karena peserta didik dapat mengakses materi pembelajaran dimanapun dan kapanpun.

\footnotetext{
${ }^{17}$ Ade Kusmana, "DALAM PEMBELAJARAN Oleh: Ade Kusmana *, Lentera Pendidikan 14, no. 1 (2011) halm 37.

${ }^{18}$ Wiwin Hartanto, "Penggunaan E-Learning Sebagai Media Pembelajaran,” Jurnal Pendidikan Ekonomi 10, no. 1 (2016) halm 4.
} 
Peserta didik dapat melaksanakan pembelajaran dan menyelesaikannya setiap saat sesuai rentang jadwal yang sudah ditentukan.

Dalam menerapkan dan mengaplikasikan pola pembelajaran e-learning harus memperhatikan beberapa prinsip-prinsip agar pembelajaran kondusif dan baik yaitu: adanya tujuan jelas, relevan dengan kebutuhan \& mutu pendidikan, efesiensi dan efektifitas program, efektifitas, pemerataan, kemandirian, keterpaduan dan kesinambungan.

Pola pembelajaran e-learning atau jarak jauh berbasis web harus memiliki beberapa unsur sebagai berikut: ${ }^{19}$

a. Pusat kegiatan peserta didik; sebagai suatu Community web based distance learning harus mampu menajadikan sarana ini sebagai tempat kegiatan peserta didik, dimana pesera didik dapat menambah kemamapuan, membaca materi peajaran, mencari informasi dan sebagainya.

b. Interaksi dalam grup; para peserta didik dapat berinteraksi satu sama lain untuk mendiskusikan materi-materi yng diberikan guru. Guru dapat hadir dalam grup ini untuk memberikan sedikit ulasan tentang materi yang diberikanya.

c. Sistem administrasi peserta didik; dimana para peserta didik dapat meilihat informasi mengenai status peserta didik dan lain-lain.

d. Pendalamana materi dan ujin

e. Perpustakaan digital, bagian ini bersifat sebagai penunjang dan berbentuk data base.

f. Materi online diluar materi pembelajaran; untuk menunjang pembelajaran diperlukan bahan bacaaan dari web lain.

Kesuksesan pembelajaran jarak jauh atau e-learning yang meninggalkan ketaatan pada jadwal seperti pada proses pembelajaran tatap muka atau tradisional, bukanlah merupakan suatu pilihan yang mudah baik bagi instrktur maupun peserta didik. Maka dari itu pembelajaran jarak jauh/e-learning memiliki keterbatasan/kelemahan sekaligus kelebihan.

Berikut kelebihan pembelajaran jarak jauh/e-learning:

a. Tersedianya fasilitas e-moderating di mana pendidik dan peserta didik dapat berkomunikasi dengan mudah melalui fasilitas internet tanpa dibatasi oleh jarak, tempat dan waktu.

b. Peserta didik dapat belajar atau mereview bahan pelajaran setiap saat

${ }^{19}$ Daryanto \& Syaiful Karim, Pembelajaran Abad 21, hal 104. 
dan dimana saja kalau diperlukan.

c. Bila peserta didik memerlukan tambahan informasi yang berkaitan dengan bahan yang dipelajarinya, ia dapat melakukan akses di internet secara mudah.

d. Baik pendidik maupun peserta didik dapat melakukan diskusi melalui internet yang dapat diikuti oleh peserta didik yang banyak, sehingga menambah ilmu pengetahuan dan wawasan yang lebih luas.

e. Peserta didik dapat benar-benar menjadi titik pusat kegiatan belajarmengajar karena ia senantiasa mengacu pada pembelajaran mandiri untuk mengembangakan diri pribadi.

Walaupun demikian, pembelajaran jarak jauh/e-learning juga tidak terlepas dari berbagai kekurangan, antara lain: ${ }^{20}$

a. Kurangnya interaksi antara pendidik dan peserta didik bahkan atar peserta didik itu sendiri. Kurangnya interaksi ini bisa memperlambat terbentuknya values dalam proses pembelajaran.

b. Kecenderungan mengabaikan aspek akademik atau aspek sosial dan sebaliknya mendorong aspek bisnis dan komersial

c. Masalah ketepatan dan kecepatan pengiriman modul dari pusat pengelolaan pembelajaran jarak jauh kepada peserta didik di daerah sering tidak tepat waktu, dan karenanya dapat mengahambat kegiatan pembelajaran,

d. Peserta didik yang tidak mempunyai motivasi belajar tinggi cenderung gagal

e. Dukungan administratif untuk proses pembelajaran e-learning dibutuhkan untuk melayani peserta didik yang mungkin sangat banyak.

\section{Kapabilitas Belajar}

Kapabilitas belajar menurut Gagne (1975) dapat di klasifikasikan menjadi lima katagori yang saling berhubungan yaitu: (1) informasi verbal (verbal information), (2) Keterampilan Intelektual (intelektual skill), (3) Strategi kognitif (cognitive strategy), (4) sikap (attitude), dan (5) Keterampilan motoric (motorskill). Dapat diilustrasikan dalam sebuah gambar yaitu: ${ }^{21}$

${ }^{20}$ Daryanto \& Syaiful Karim, halm 102.

${ }^{21}$ Wasis D. Dwiyogo, Pemebelajaran Berbasis Blended Learning, halm 28. 


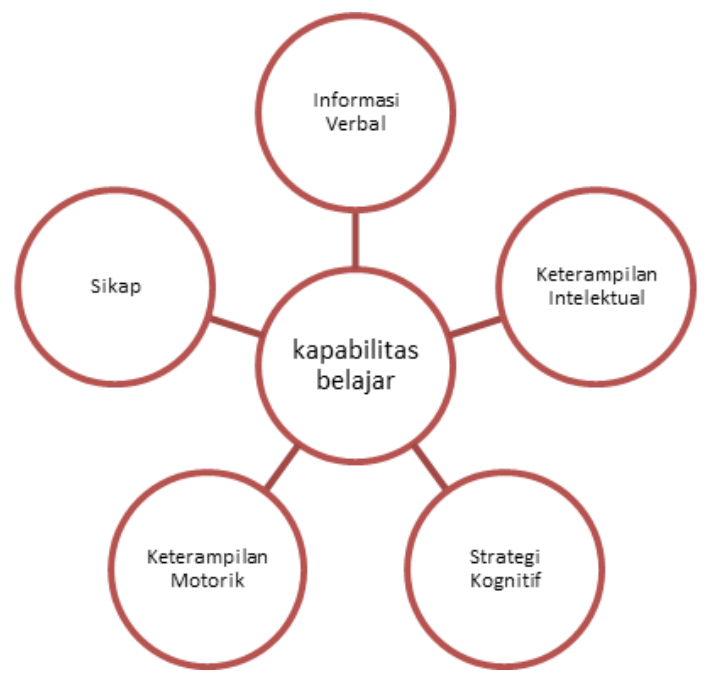

Gambar 2.1. Kapabilitas Belajar Menurut Gagne (1975)

a. Informasi Verbal

Informasi verbal biasanya juga disebut sebagai pengetahuan verbal, nama lain informasi verbal adalah pengetahuan deklaratif. Belajar informasi verbal berisi tentang belajar nama-nama, fakta-fakta, dan mengorganisasi informasi, semua jenis ini menunjukan pengetahuan deklaratif.

b. Keterampilan Intelektual

Keterampilan intelektual dibagi kedalam sub kategori yang dapat di urutkan sesuai dengan kemitraan kerja mental di dalamnya. Sub kategori ini berkaitan satu dengan yang lainya artinya keterampilan inteletual meliputi deskriminasi, konsep konkret, konsep definisi dan hukum, hukum yang lebih tinggi dan pemecahan masalah.

c. Strategi kognitif

Strategi kognitif adalah proses untuk mengontrol secara internal dalam memilih dan memodifikasi untuk mengatur belajar, mengingat, dan berpikir, terutama digunakan pada waktu pemecahan masalah. Kategori strategi kognitif meliputi strategi pengulangan, strategi elaborasi, strategi organisasi, stategi monitoring komprehensif. 


\section{d. Sikap}

Sikap adalah kapibilitas belajar yang terbentuk secara internal dan memengaruhi pilihan tindakan mana yang akan di ambil. Misalnya, diharapkan para siswa memiliki sikap tertentu yang mempengaruhi interaksi sosial mereka, seperti toleransi terhadap perbedaan suku, golongan, kasih sayang sesama, tolong menolong dan tenggang rasa dengan orang lain.

e. Keterampilan motorik

Keterampilan motrorik merupkan kapabilitas belajar yang didasarkan pada performansi yang dihasilkan dari kecepatan, ketepatan, kekuatan atau kehalusan gerak tubuh.

\section{METODE}

Berdasarkan fokus, tujuan, dan karakteristik data yang dikumpulkan maka penelitian ini menggunakan pendekatan kualitatif, jenis penelitianya studi kasus (case study) dan dalam pengumpulan data peneliti sendiri sebagai instrumen utama. Dengan maksud untuk menggali dan eksplorasi data secara mendalam dengan menganalisis apa yang sebenarnya terjadi di balik fakta atau kasus. Dalam memproleh data penelitian menggunakan beberapa metode meliputi wawancara, observasi, dan dokumentasi. Penelitian ini bertempat di Universitas Alma Ata Yogyakarta.

\section{HASIL PENELITIAN \\ 1. Mengapa Blended Learning}

Berdasarkan hasil pengamatan penulis dalam web Universitas Alma ata, alasan mengapa teori pembelajaran blended learning di terapkan sebagai berikut. Pada mulanya penerapan pembelajaran Blended learning merupakan suatu upaya pemerintah dalam mengahadapi era revolusi industri 4.0, pemerintah mendorong penggunaan metode e-lerarning dalam sistem pembelajaran di perguruan tinggi. Menteri Riset, Teknologi, dan Pendidikan Tinggi Mohamad Nasir menargetkan penerapan perkuliahan daring atau e-learning di perguruan tinggi bisa dilaksanakan pada 2018.

Dengan adanya instruksi dari pemerintah, Universitas Alma Ata kemudian menerapkan sistem pembelajaran berbasis digital atau e-learning akan tetapi dalam penerapanya universitas Alma Ata tidak menerapkan secara full pembelajaran e-learning melainkan dengan mengkombinasikannya dengan pembelajaran tatap muka atau biasa disebut dengan pola pembelajaran konvensonal. Dengan hal ini peneliti dapat mengambil garis merah bahwa 
pola pembelajaran yang di terapkan oleh universitas Alma Ata merupakan Pola pembelajaran blended learning yaitu pola pembelajaran yang mengkombinasikan antara pola pembelajaran konvensional dengan pola pembelajaran berbasis digital atau e-learning.

Pembelajaran blended learning di universitas Alma ata dilaksanakan di seluruh fakultas hal ini diharapkan agar mampu menunjukkan peran internet di dunia pendidikan serta dapat meningkatkan sistem manajemen pembelajaran yang lebih baik.

\section{Konsep Pembelajaran Blended Learning di Universitas Alma Ata}

Berdasarkan hasil wawancara dengan beberapa mahasiswa/I Universitas Alma ata memperoleh data sebagai berikut; Dalam proses pelaksanaanya, blended learning terbagi menjadi dua bagian, bagian yang pertama; dilakukan dengan proses pembelajaran secara tradisional dan bagian kedua; secara $e$-learning. Adapun jumlah pertemuan antara keduanya dalam semester terdapat 14 kali pertemuan, dari pertemuan ini untuk pembelajaran berbasis e-learning mendapatkan 3 kali pertemuan dan 11 pertemuan sisanya di gunakan untuk pembelajaran secara konvensional.

Pembelajaran berbasis e-learning Universitas Alma ata di terapkan dengan menggunakan sistem web, di mana seluruh mahasiswa/I mempunyai Akun dan Id masing-masing, dan dapat di akses dimanapun dan kapanpun mereka mau, dengan bantuan alat elektonik seperti handpone, computer dan laptop dengan jaringan internet. Adapun proses pembelajaran berbasis e-learning sendiri dilakukan ketika dosen menetapkan pertemuannya menggunakan e-learning, dengan hal itu ketika pembelajaran e-learning berlangsung seluruh mahasiswa/I dan dosen masuk melalui web e-learning kemudian memilih fakultas dan jurusan kemudian memilih mata kuliah, setelah pemilihan mata kuliah kemudian mahasiswa memilih tombol kehadiran untuk menandakan bahwa ia hadir dalam pembelajaran e-learning tersebut.

Ada beberapa katagori pembelajaran yang terjadi yaitu kategori yang pertama, pembelajaran dari dosen yaitu dosen memberikan arahan tentang materi yang akan di bahas pada pertemuan ketika itu, kemudian dosen meminta untuk membacanya dan mengajukan pertanyaan bagi yang belum di pahami kemudian adanya penugasan untuk mahasiswa.

Adapun katagori yang kedua yaitu melanjutkan makalah dari mahasiswa/I yang bertugas pada hari itu, mahsiswa/I yang bertugas diminta untuk menguploud materi/ makalah yang akan di bahas kemudian dilanjutkan dengan diskusi online, yaitu bagi mahsiswa yang mau bertanya diminta untuk 
menuliskan pertanyaan dan mengirim langsung. Setelah pertanyaan tersebut dikirimkan petugas pemakalah menjawabnya dengan mengirimkan kembali jawabannya.

Berikut proses pembelajaran e-learning berbasis web di Universitas Alma Ata:

\section{Topik 11. Geostrategi dan K€}

Assalamu'alaikum Wr Wb

Anak-anaku semua dalam materi ini kita kan membahas tentang:

a. Makna Ketahanan Nasional dan

b. Tujuan dan Landasan Tujuan Nasional

c. Latar Belakang Ketahanan Nasional

d. Konsepsi Dasar Ketahanan Nasional

e. Asas-Asas dan Fungsi mempelajari

Ketahanan Nasional

Refrensi: Kementerian Riset Teknologi dan Pendidikan Tinggi Republik

Indonesia, Pendidikan Kewarganegaraan

Tingluk Perguruan

AN-KEWARGANEGARAAN-

1.pof

므 Quis

store $\times$ TELCO

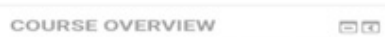

Ushul Fiqh

There are new forum pe

\section{Alquran}

Wi] There are new forum pe

Bahasa

Inggris 1

(Kelas B)

13 You have assignments

till There are new forum pe

IImu Kalam

Gambar 3.1. Web E-learning Universitas Alma Ata

Tanggapan beberapa mahasiswa dalam proses pembelajaran e-learning terdapat beberapa katagori tanggapan yang berbeda-beda, ada mahasiwa yang mengatakan dengan adanya pembelajaran e-learning mereka merasa senang dengan alasan mampu memanfaatkan teknologi sebagai suatu yang bernilai positif yaitu belajar mereka sangat termotivasi dengan adanya pola pembelajaran e-learning, kemudian mereka juga mengatakan bisa belajar dimana saja, kapan saja dan dengan situasi seperti apapun, materi pembelajaran dapat di baca dan di baca ulang kapanpun mereka mau. Akan tetapi ada mahasiswa juga yang berpendapat bahwa pola pembelajaran e-learning membuatnya tidak bersemangat untuk belajar, bahkan ada yang mengatakan e-learning seperti halnya libur dan ketika masuk web hanya absen kemudian tidak memperhatikan bagaimana proses pembelajaran e-learning tersebut berlangsung, dan juga mereka menganggap bahwa pembelajaran tidak fokus karena dalam pembela- 
jaran e-learning terganggu dengan adanya aplikasi lainya yang ada handpone seperti tiba-tiba ada chat whatshap, instagram dll. Dan mereka juga mengatakan bahwa dalam pembelajaran e-learning dosen tidak bisa mengawasi dan mengetahui apa kita memperhatikan atau tidak dan kurangnya interaksi dosen juga dalam pembelajaran tersebut.

Selain pembelajaran e-learning universitas Alma ata juga masih menerapkan pola pembelajaran konvensional, yang mana pembelajaran konvensional dilaksanakan 11 kali pertemuan, dalam proses pelaksannaya kelas tradisional menggunakan system tatap muka langsung dengan dosen, dan menngunakan beberapa metode seperti diskusi, peraktek, ceramah dan pembelajaran berbasis pemecahan masalah. Dalam pembelajaran konvensional/tradisional proses pembelajaran diskusi di dalam kelas masih sangat dominan dan sering di lakukan, yaitu dengan mahasiswa membuat suatu tugas makalah kemudian di diskusikannya di hadapan teman-teman kemudian terdapat proses Tanya jawab dan berdialek mempertahankan dan mempertanggungjawabkan makalah yang telah di buatnya.

Adapun dalam perakteknya pembelajaran disesuaikan dengan mata kuliah yang di pelajarinya, misalnya terdapat beberapa peraktek ketika pembelajaran berbasis penyelesaian masalah, dosen memberikan tugas kepada mahasiswa untuk memperhatikan daerah sekitarnya, dan menemukan permasalahan serta solusi dalam mengatasinya, penugasan ini biasanya berbentuk penugasan seperti halnya mini riset.

\section{Implementasi Teori Pembelajaran Blended Learning}

Implementasi teori blended learning dalam meningkatkan kapabilitas belajar di prodi PAI Universitas Alma Ata pada era digital terdapat beberapa poin yang dapat di analisis, seperti halnya pola pembelajaran blended learning yang di lakukan di Alma Ata dalam pola pembelajaran yang dilakukan di Alma Ata mengalokasikan pertemuan 3 kali untuk e-learning dan 11 kali untuk pembelajaran tatap muka, hal ini sesuai dengan komposisi pola pembelajaran blended learning yaitu $75 \%$ untuk pola pembelajaran tradional dan $25 \%$ untuk pembelajaran e-learning.

Teori blended learning mampu meningkatkan kapabilitas belajar peserta didik/mahasiswa/I di Era digital hal ini dapat dibuktikan dalam pola pembelajaran belended learning yang mengkombinasikan antara pola pembelajaran e-learning dan pola pembelajaran konvensional. Dalam kapabilitas belajar sendiri ada bebarapa point yang saling berhubungan yaitu informasi verbal (verbal information), keterampilan Intelektual (intelektual skill), Strategi 
kognitif (cognitive strategy), sikap (attitude), dan keterampilan motorik (motorskill). dalam pengaplikasian kelima aspek kapabilitas tersebut teori blended learning telah mengklasifikasikannya yaitu.

Beberapa aspek yang masuk pada pembelajaran blended learning dalam katagori pembelajaran berbasis e-learning yaitu aspek kognitif/starategi kognitif dan informasi verbal mengapa kedua aspek ini lebih condong dalam pembelajaran e-learning, hal ini di sebabkan karena pola pembelajaran e-learning seperti dalam temuan penelitian yang lebih menekankan kepada penugasan dari dosen dan diskusi makalah mahasiswa yang berupa bacaan atau makalah yang kemudian makalah tersebut di duskusikan dengan beberapa pertanyaan oleh mahasiswa. Dengan hal ini menunjukan bahwa informasi verbal yang berupa keilmuan yang harus di kuasai oleh peserta didik.

Disamping itu dengan adanya pembelajaran berbasis e-learning sendiri memudahkan peserta didik mengakses dan belajar kapanpun dan dimanapun mereka mau untuk belajar, hal ini dengan adanya system pemanfaatan teknologi yang baik dan efesien karena dalam pembelajarannya sudah tersistem dengan baik berupa web.

Akan tetapi dalam proses pembelajaran sendiri tidak hanya aspek pengetahuan yang harus di kuasai oleh peserta didik. Melainkan aspek-aspek lainya juga harus di kuasai oleh peserta didik seperti halnya aspek sikap spritutal maupun sosial kemudian aspek keterampilan agar peserta didik menjadi seseorang yang bagus dalam hard skill maupun soft skill nya.

Oleh karenanya dalam pembelajaran blended learning masih menitik beratkan pola pembelajaran konvensional hal ini agar peserta didik mampu bersikap baik dan mempunyai keterampilan yang mumpuni dalam mengahadapi Era digital. dalam kapabilitas belajar yang masuk kedalam pola pembelajaran blended learning dalam katagori pembelajaran konvensional yaitu keterampilan intelektual, keterampilan motoric dan sikap, aspek kogitif dan informasi verbal. Dalam pola pembelajaran ke lima aspek kapabilitas pembelajaran menurut gagne keseluruhannya masuk. Hal ini di karenakan dalam pola pembelajaran konvensional guru juga memberikan informasi verbal berupa keilmuan-keilmuan. Akan tetapi hal yang tidak dalam pembelajaran e-learning yaitu adanya kontak/hubungan langsung dengan pendidik.

Pola pembelajaran konvensional sendiri sesuai data temuan menunjukan bahwa peran seorang guru atau pendidik sangatlah penting dikarenakan peran pendidik sendiri bukan hanya mentransfer keilmuan saja melainkan memberikan contoh yang baik kepada peserta didik, Al Ghozali mengatakan bahwa pendidik merupakan muallim, mudarris, muadiib dan murobbi. 
Pembelajaran konvensional/tradisonal secara tidak langsung memberikan peluang besar bagi pendidik untuk menjalankan perannya yaitu dengan memberikan keteladanan bagi peserta didik, hal inibertujuan agar peserta didik meniru dan meneladani sikap yang baik yang ada dalam diri pendidik, dalam kata lain seorang pendidik merupakan figur utama dalam pembelajaran, begitu halnya dengan sikap sosial yang lainya dapat ditumbuhkan melalui adanya diskusi, dan saling menghormati pendapatan temanya.

Selain aspek sikap pola pembelajaran konvensioanal juga melibatkan aspek psikomotorik atau keterampilan, hal ini berdasarkan hasil temuan menunjukan bahwa dalam pembelajaran konvensional melibatkan aspek keterampilan yaitu pendidik atau dosen dalam lingkungan perguruan tinggi biasanya menggunakan penugasan di luar sekolah/kampus, seperti halnya penugasan mini riset, dalam hal ini mahasiswa diharapkan mampu mendapatkan suatu masalah dan mampu memberikan solusi yang baru dan kontekstual yang diterima oleh seluruh elemen/masyarakat.

\section{E. KESIMPULAN}

Implementasi teori blended learning dalam menyeimbangkan kapabilitas belajar pada era digital di prodi PAI Universitas Alma Ata terbagi dalam dua klasifikasi yaitu pembelajaran blended learning merupakan kombinasi antara pola pembelajaran berbasis e-learning dan pola pembelajaran konvensional atau tradisional. Pada klasifikasi pertama dalam pembelajaran blended learning merupakan pola pembelajaran e-learning, kapabilitas belajar yang terkalasifikasi dalam pola pembelajaran ini yaitu kapabilitas informasi verbal dan stategi kognitif hal ini dikarenakan dalam dalam pembelajaran e-learning lebih menitik beratkan kepada aspek pengatahuan. Sedangkan klasifikasi yang kedua yaitu pola pembelajaran blended learning yang mana kapabilitas yang masuk dalam pembelajaran ini meliputi kelima aspek tersebut yaitu informasi verbal, strategi pengetahuan, keterampilan intelektual, sikap dan keterampilan motoric. Akan tetapi terfokus dari kelima asek tersbut dalam pembelajaran konvensioanl pada teori blended learning lebih menekankan tiga aspek yang meliputi sikap dan keterampilan. Hal ini dikarenakan dalam pembelajaran konvensional melibatkan langsung peran seoarang pendidik, dan menjadikan seorang guru sebagai sentral figur, yang berperan penting dalam membentuk pribadi peserta didik. 


\section{DAFTAR PUSTAKA}

Abdullah, Walib. "Model Blended Learning Dalam Meningkatkan. "FIKROTUNA" no. 1 (2018): 855-66.

Ade Kusmana. "DALAM PEMBELAJARAN Oleh: Ade Kusmana*." Lentera Pendidikan 14, no. 1 (2011): 35-51.

Ali Alammary, Judy Sheard, Angela Carbone. "Blended Learning In Higher Education: Three Different Aproaches." Australian Journal of Educational Technology 1, no. 3 (2014): 30-40.

Antony G. Piccianon, Charles D, Dziuban, charkes R Graham. Blended Learning Research Perspective. New York: Routledge, 2014.

Arif Rahman \&DKK. Pendidikan Islam Di Era Revolusi Industri 4.0. Yogyakarta: Komojaya Press, 2019.

Daryanto \& Syaiful Karim. Pembelajaran Abad 21. Yogyakarta: Gaya Media, 2017.

Hartanto, Wiwin. "Penggunaan E-Learning Sebagai Media Pembelajaran." Jurnal Pendidikan Ekonomi 10, no. 1 (2016): 1-18.

Husamah. Pembelajaran Bauran (Teori Blended Learning). Malang: Prestasi Pustaka, 2014.

Ibrahim. "Perpaduan Model Pembelajaran Aktif Konvensional (Cermah) Dengan Cooperatif (Make-a Match) Untuk Meningkatkan Hasil Belajar Pendidikan Kewarganegaraan." Jurnal Ilmu Pendidikan Sosial, Sains Dan Humaniora 3, no. 2 (2017): 199-212.

Idris, Husni. "Pembelajaran Model Blended Learning." Jurnal Ilmiah Iqra' 5, no. 1 (2018): 61-73.

.Kuntarto \&DKK. "Pengembangan Model Pembelajaran Blended Learning Pada Aspek Learning Design Dengan Platform Media Sosial Online Sebagai Pendukung Perkuliahan Mahasiswa," 2016. http:// repository.unja.ac.id/626/1/Artikel Jurnal-Blended Learning.pdf.

Ruchi Shivam, Sunita Sungh. "Implementation of Blended Learning In Classroom: A Review Paper." International Journal of Scientific and Research Publication 20, no. 1 (2015).

Suparta. Pengantar Dan Aplikasi Pengembangan Kurikulum PAI. Jakarta: Rajawali, 2016.

Wasis D. Dwiyogo. Pemebelajaran Berbasis Blended Learning. Depok: Rajawali Press, 2018.

Widiara, I Ketut. "Blended Learning Sebagai Alternatif Pembelajaran Di Era Digital." Purwadita 2, no. 2 (2018): 50-56. 